\title{
Americanism, Un-Americanism, and the Gay Rights Movement
}

\author{
SIMON HALL
}

The issue of "un-Americanism" was present at the creation of the gay rights movement. Indeed the movement emerged, at least in part, as a response to wide-ranging discriminatory policies and practices that were implemented by the federal government during the Cold War. Faced with claims that they constituted an existential threat to the United States, activists in the early gay rights movement worked hard to affirm their patriotism and appealed frequently to the nation's founding ideals of liberty and equality. At times, they also characterized those who discriminated against them as "un-American." Fifty years later, debates about "Americanism" and "un-Americanism" have been centre stage in the battle to repeal Don't Ask, Don't Tell and to secure gay marriage rights. With conservative politicians, commentators and activists claiming that demands for gay marriage threaten the foundation of American civilization, the gay rights movement and its supporters have responded in kind. The increased willingness of gay rights activists to lay the charge of "un-American" is, at one level, a logical extension of the appeal to Americanism that has long been central to the movement's rhetorical and symbolic approach. But it also reflects both the greater empowerment of today's LGBT community compared with their McCarthy-era predecessors and the divisiveness of contemporary American political culture.

The issue of "un-Americanism" was present at the creation of the gay rights movement. Indeed, the movement emerged, at least in part, as a response to wide-ranging discriminatory policies and practices that were implemented by the federal government supposedly to bolster the nation's internal security during the Cold War. Faced with claims that they constituted an existential threat to the United States, activists in the early gay rights movement worked hard to affirm their patriotism, and they appealed frequently to the nation's founding ideals of liberty and equality. One occasion, they even characterized those who discriminated against them as "un-American." Fifty years later, the rhetoric of "Americanism" and the "un-American" has been centre stage in the gay rights movement's battle to secure marriage rights and repeal Don't Ask, Don't Tell. Accusing opponents of gay rights of engaging in un-American behaviour is, at one level, a corollary to the appeal to Americanism that has long been central to the movement's rhetorical and symbolic approach.

School of History, University of Leeds, UK. Email: s.d.hall@leeds.ac.uk. The author would like to thank the two anonymous reviewers for their helpful comments on an earlier version of this essay. 
But the increased willingness of gay rights activists to level this charge appears to be symptomatic of the divisiveness of the nation's contemporary political culture following three decades of the "culture wars." Moreover, activists' use of patriotic forms of protest raises interesting and at times troubling questions about the relationship between the gay rights movement and American nationalism.

In recent years a number of historians have argued convincingly that, during the early Cold War, homophobia was an integral part of the anticommunist crusade at home. In February 1950, following Undersecretary of State John Purifoy's revelation that his department had recently fired a large number of homosexuals, fears about the security risks posed by so-called "sexual perverts" spread quickly. Before long, Republicans in Congress were using the issue to attack the Truman administration. Senator William E. Jenner, a Republican from Indiana, denounced the "New Deal, Fair Deal and fairy deal administrations." "Viewed as emotionally unstable, of weak moral fibre, and vulnerable to blackmail, homosexuals were cast as a serious threat to the moral health and security of the United States by both politicians and journalists. ${ }^{2}$ Senator Joseph McCarthy, for instance, warned that "once the people of a Nation become complacent about moral degeneracy in its leadership, then the nation has not long to live." 3 In a newsletter sent to party workers, GOP chairman Guy George Gabrielson suggested that the "sexual perverts" who had "infiltrated" the government were "perhaps as dangerous as the actual Communists." 4 Tabloid journalist Arthur Guy Matthews even claimed that communists were seeking to convert America's youth to homosexuality in a bid to defeat the United States from within. Homosexuality, he said, was "Stalin's Atom Bomb."s Nebraska's Senator Kenneth Wherry, who played a leading role in the effort to "root out" suspected homosexuals from the federal government, went so far as to assert that a list of homosexuals from around the world, which had originally been compiled by the Nazis, had fallen into the hands of the Russians who were now planning to use homosexuals

${ }^{I}$ David K. Johnson, The Lavender Scare: The Cold War Persecution of Gays and Lesbians in the Federal Government (Chicago: The University of Chicago Press, 2006), 16-17, 18-20, 28-30, 38-39; John D’Emilio, “The Homosexual Menace: The Politics of Sexuality in Cold War America," in Kathy Peiss and Christina Simmons, eds., Passion and Power: Sexuality in History (Philadelphia: Temple University Press, 1989), 226-40, 227-28.

${ }^{2}$ D'Emilio, 228. ${ }^{3}$ Johnson, 37.

${ }^{4}$ Randolph W. Baxter, " "Homo-Hunting" in the Early Cold War: Senator Kenneth Wherry and the Homophobic Side of McCarthyism," Nebraska History, 4 (Fall 2003), I I 9-32, I 25.

${ }^{5}$ Johnson, 37. 
in America to "gain their treacherous ends." If, as historian Carolyn Herbst Lewis has put it, homosexuality came to be seen as "the greatest threat to American life," then "heteronormativity" constituted a bulwark of American identity and nationalism. ${ }^{7}$ Within this framework, the family became both a symbol of, and an institution that nurtured, American values: "the American home, populated by a heterosexual couple and their children, became, symbolically and literally, a fortress against the anxieties provoked by the Cold War."

Ultimately, the Cold War conflation of homosexuality with communism, and the widely held prejudice that homosexuals were security risks, ruined the lives of numerous Americans. Shortly after assuming office, President Eisenhower issued an executive order that made "immoral conduct" or "sexual perversion" sufficient reason for the termination of federal employment on the grounds of national security.9 Perhaps as many as ten thousand real or suspected homosexuals lost their jobs with the federal government, or were discharged "less than honorably" from the military, during the I950s. ${ }^{10}$ Countless more, of course, were denied opportunities as a result of the blanket ban.

This "pink scare," though, also shaped the early gay rights movement in important ways. As they began to organize in the late 1950 s and early 1960 , gay rights activists vigorously contested accusations that they were a security risk, a source of national weakness, and a threat to the nation's health. In fact, they sought to turn these arguments on their head by laying claim to full citizenship rights in the context of America's Cold War fight for freedom. In the words of David K. Johnson, gay activists "wrapp[ed] themselves, metaphorically at least, in the American flag." I I In adopting this approach, gay rights activists were following in a rich and deep-rooted tradition of patriotic protest. Abolitionists, labour organizers, and advocates of women's suffrage were just some of those who had invoked the Declaration of Independence and the Constitution, and sought to present themselves as the heirs of the Revolutionary tradition, to advance their particular cause. ${ }^{12}$ But America's

\footnotetext{
${ }^{6}$ Baxter, 126.

${ }^{7}$ Carolyn Herbst Lewis, Prescription for Heterosexuality: Sexual Citizenship in the Cold War Era (Chapel Hill: University of North Carolina Press, 2010), 3-4, 7, 25.

${ }^{8}$ Ibid., I 4 I.

${ }^{9}$ D'Emilio, 229; Executive Order I0450 at www.archives.gov/federal-register/codification/ executive-order/ I $0450 . h t m l$ accessed 2 March 2012.

${ }^{10}$ Baxter, I 28. On the relationship between the Cold War, homosexuality and the state see also Margot Canaday, The Straight State: Sexuality and Citizenship in Twentieth-Century America (Princeton: Princeton University Press, 2009), chapters 5 and 6.

${ }^{11}$ Johnson, $20 \mathrm{I}$.

${ }^{12}$ See Michael Kazin and Joseph A. McCartin, "Introduction," in Kazin and McCartin, eds., Americanism: New Perspectives on the History of an Ideal (Chapel Hill: University of North
} 
Cold War leadership of the "free world" and the accompanying red scare at home that sought to tar political dissenters and progressive activists as communists or communist sympathizers proved a powerful additional incentive. Homophile activists were also influenced by the contemporaneous black struggle for civil rights - in which patriotism played a highly visible, and effective, role. During the sit-in protests against segregation that erupted during the spring of 1960 , for example, the young student activists worked hard to assert their patriotism while simultaneously urging the United States to live up to its own high ideals. In Atlanta, for instance, the sit-in protesters declared that they could no longer "tolerate, in a nation professing democracy ... the discriminatory conditions under which the Negro is living today," and made clear their determination to "secure full citizenship rights as members of this great Democracy of ours." 13

A good example of the homophile movement's use of patriotism comes from the Mattachine Society of Washington (MSW). Founded in 196r by Jack Nichols and Franklin Kameny (an astronomer who had been fired from the US Map Service in 1957 for being gay), the organization was at the cutting edge of the struggle for gay rights during the first half of the 1960 s, and played a leading role in the adoption of direct-action protests. Patriotism and the invocation of Americanism (appeals to the Declaration of Independence; the American Dream; and the nation's founding principles of freedom, liberty and equality) were at the heart of the group's rhetorical approach. Its constitution, for example, declared that the MSW's purpose was to "act by any lawful means" to "secure for the homosexual the right to life, liberty, and the pursuit of happiness, as proclaimed for all men by the Declaration of Independence, and to secure ... the basic rights and liberties established by the word and the spirit of the Constitution." ${ }^{4}$

Appeals to Americanism also featured strongly in the direct-action demonstrations in which MSW activists participated, along with comrades from the Mattachine Society of New York, Philadelphia's Janus Society, and the Daughters of Bilitis - a lesbian organization. At a picket of the

Carolina Press, 2003), I-2 I, 3, Woden Teachout, Capture the Flag: A Political History of American Patriotism (New York: Basic Books, 2009); and Simon Hall, American Patriotism, American Protest: Social Movements since the Sixties (Philadelphia: University of Pennsylvania Press, 20 I I), 6.

${ }^{13}$ Atlanta Committee on Appeal for Human Rights, "An Appeal for Human Rights," in Clayborne Carson et. al., eds., The Eyes on the Prize Civil Rights Reader: Documents, Speeches, and Firsthand Accounts from the Black Freedom Struggle, 1954-19go (New York: Penguin, I991), II7.

14 "Constitution of the Mattachine Society of Washington," in The Gay Rights Movement: Mattachine Society of New York, Inc.; from the International Gay Information Center, New York Public Library, microfilm (New York: Research Publications International, 1998) (hereafter MSNY), Series 3, Gay Organizations, Reel I 8, Box 8, Folder 5. 
White House on 29 May 1965, for example, signs carried by the dozen or so protesters read "First Class Citizenship for Homosexuals," "Homosexuals are American Citizens, Too" and "US Claims No Second Class Citizens; What About Homosexual Citizens?" "s A few months later, at a 4 July demonstration outside Philadelphia's Independence Hall - the first of the annual "reminders" that would take place for the rest of the decade - placard slogans included "America - the land of opportunity. For homosexuals too?"; "The American way: Employment based upon competence, ability, training, NOT upon private life"; and "America, the land of the free. For homosexuals too?" ${ }^{6}$ For the protest the following year, one activist from MSNY even composed a special version of The Battle Hymn of the Republic ("Now We Are Marching On"), which contained the following verses:

Your masquerading morals squad has twisted all we've said, You've put peepholes in our bathrooms, and made laws to rule our bed,

We ask you to treat us fairly but you always turn your head,

Now we are marching on.

In your so-called "Great Society" you've given us no place,

We bring to you our problems, and you stand and slap our face,

How can you boast of freedom and ignore this great disgrace,

Now we are marching on. ${ }^{17}$

Gay rights activists also claimed that, rather than strengthening the nation, the automatic exclusion of homosexuals from the military and federal government was actually a source of weakness. Wasting "useful talent and manpower" was, declared the MSW, "not consistent with the national welfare." ${ }^{18}$ The group singled out the US Civil Service Commission's refusal to employ homosexuals not just as "discriminatory" and "unconstitutional," but as operating "against the best interests of the country" by depriving "the nation of the service of many clearly well-qualified citizens who have much to offer." 19 Furthermore, they argued that by forcing gay employees to keep their sexuality secret for fear of dismissal, the security-clearance system actually created the possibility for blackmail that was, supposedly, at the root of the national security weakness. ${ }^{20}$

\footnotetext{
is "Information Bulletin," MSNY, Series 3, Gay Organizations, Reel I 8, Box 8, Folder 5.

16 "Information Bulletin," MSNY, Series 3, Gay Organizations, Reel I 8, Box 8, Folder 5.

17 "Now We Are Marching On," MSNY, Series 2, Topical File, Reel 9, Box 3, Folder 2 I.

18 "News Release from the Mattachine Society of Washington," 28 Aug. 1962, I-2, MSNY, Series 3, Gay Organizations, Reel i 8, Box 8, Folder 5.

19 "News Release from the Mattachine Society of Washington," 28 Aug. 1962, I-2, MSNY, Series 3, Gay Organizations, Reel i 8, Box 8, Folder 5.

20 "News Release from the Mattachine Society of Washington," 28 Aug. 1962, I-2, MSNY, Series 3, Gay Organizations, Reel i 8, Box 8, Folder 5.
} 
During the first half of the 1960 , gay rights organizations argued repeatedly that the discriminatory measures that had been justified on the grounds of national security ran counter to America's ideals. In explaining their decision to protest outside the Pentagon on 3 I July 1965, for example, Mattachine activists argued that "in their mania to ferret out homosexuals" the armed forces had "dispense[d] with traditional American concepts of due process, of constitutional guarantees" and so on and, instead, "resort[ed] to entrapment, intimidation, coercion" and "threats." The result, they claimed, was "a mockery of everything for which our Armed Services supposedly exist." ${ }^{21}$ In February I 966 fifteen gay rights organizations, representing homosexuals in every state of the union, adopted a statement during a convention in Kansas City that denounced the "disqualification of homosexuals, as a group or class, from receipt of security clearances" as "unjustified and contrary to fundamental American principles." ${ }^{22}$ The implication of all this was that antigay discrimination was itself un-American. Although this charge often went unspoken, some of those who protested outside the Civil Service Commission building on 26 June 1965 carried placards that read "Civil Service Commission is Un-American." ${ }^{23}$ Furthermore, in a press release MSW described what it termed the "un-American refusal of the Civil Service Commission to meet with" gay rights leaders - "a meeting with their public officials which citizens in a democracy should be able to expect as a matter of right." ${ }^{24}$

\section{III}

In the first flush of the gay liberation movement that followed the Stonewall Riot of 28 June 1969, many activists and organizations embraced Revolutionary politics and radical rhetoric. New York's Gay Liberation Front (GLF), for example, talked of "break[ing] the chains" of "a racist, sexist, imperialist system," denounced the "imperialist" war in Vietnam, and offered support for Black Power. Rejecting the assimilationist model, many gay liberation groups also abandoned the patriotic strategies of their homophile predecessors and, rather than invoking the American Dream, instead lashed out at "Amerika." ${ }^{5}$

\footnotetext{
2r "Why Are Homosexual Citizens Picketing the Pentagon?", 3, MSNY, Series 2, Topical File, Reel 9, Box 3, Folder 2 I.

22 "The National Planning Conference of Homophile Organizations," MSNY, Series 2, Topical File, Reel 13 , Box 5, Folder 2.

23 "Information Bulletin," MSNY, Series 3, Gay Organizations, Reel i 8, Box 8, Folder 5.

${ }^{24}$ Mattachine Society of Washington, Press Release, "Homosexuals to Picket U. S. Civil Service Commission,” 24 June 1965, MSNY, Series 2, Topical File, Reel 9, Box 3, Folder 2 r.

${ }^{25}$ Lilliam Faderman and Stuart Timmons, Gay L. A.: A History of Sexual Outlaws, Power Politics, and Lipstick Lesbians (New York: Basic Books, 2006), 172-73; Hall, American Patriotism, American Protest, 35-39.
} 
The radical tradition pioneered by the likes of the GLF has remained important. The manifesto issued by Queer Nation in the summer of 1990 , for example, argued,

Being queer is not about a right to privacy; it is about the freedom to be public, to just be who we are. It means everyday fighting oppression; homophobia, racism, misogyny, the bigotry of religious hypocrites and our own self-hatred ... Being queer means leading a different sort of life. It's not about the mainstream, profitmargins, patriotism, patriarchy or being assimilated. It's not about executive directors, privilege and elitism. It's about being on the margins, defining ourselves; it's about gender-fuck and secrets, what's beneath the belt and deep inside the heart; it's about the night. ${ }^{26}$

A series of local, grassroots insurgencies, rather than an organization in any formal sense, Queer Nation relied heavily on short-term, visible, and provocative protests, such as "kiss-ins," to challenge homophobia, and their approach was encapsulated in the slogan "We're Here. We're Queer. Get Used to It." ${ }^{27}$ While undoubtedly significant and influential, the prominence afforded to the GLF, Queer Nation, and similar groups has, at times, worked to obscure the fact that appeals to Americanism have remained an important feature of the gay rights movement since Stonewall. For instance the Gay Activists Alliance (GAA), a leading force on the East Coast during the first half of the r 970 , sought consistently to use the nation's founding ideals and documents in making the case for gay rights. This can be seen in its efforts to repeal New York State's sodomy statute. Under the state's penal code, consensual sodomy was classified as a Class B misdemeanor punishable by a five-hundred-dollar fine, three months in prison, or both. A revised code, omitting consensual sodomy, had been rejected by the state legislature in 1965 . In its 1974 campaign leaflet, "Repeal the New York Consensual Sodomy Statute!", which was written by John Lauritsen, a market research analyst, writer, and activist, the GAA argued, "As the Bicentennial of the United States approaches, it might be well to consider anew the philosophy of freedom on which the republic was founded." They also invoked the Declaration of Independence by declaring that it was time to "recognize that sexual freedom is a necessary part of every human being's right to pursue happiness." The GAA's political action committee distributed the leaflet to every member of the state legislature in an effort, ultimately unsuccessful, to get the measure repealed.

${ }^{26}$ For Queer Nation Manifesto see www.actupny.org/documents/QueersReadThis.pdf, accessed Io January 2013.

${ }^{27}$ For a short discussion of Queer Nation see www.glbtq.com/social-sciences/queer_nation. html, accessed Io Jan. 2013. See also Marc Stein, Rethinking the Gay and Lesbian Movement (New York: Routledge, 20 I 2), chapter 6, esp. ı 84-86. 
Declared unconstitutional by New York's Court of Appeals in 1980, it was repealed formally by the legislature on 22 June $2000 .{ }^{28}$

During 1976, the year of America's bicentennial celebrations, gay rights activists were particularly keen to invoke the language and symbols of the nation during the summer's gay pride celebrations - albeit sometimes with a humorous, kitsch, or camp twist. "It wasn't exactly what the Founding Fathers would have had in mind", noted the Chicago Tribune's report of that year's New York pride. "There, perched high on a float was Betsy Ross - in drag - stitching a flag". ${ }^{29}$ Many of the more than forty floats carried the "message of gay ... liberation in a red, white, and blue motif." Slogans included "Let freedom ring [for gay people too]" and "Happy Birthday, America - Can we have a piece of freedom cake?" $3 \circ$ In Los Angeles, gay rights activists held their pride on 4 July itself, and the march - organized by Christopher Street West - was replete with patriotic imagery. ${ }^{3}{ }^{\text {I }}$ The banner that led the parade featured two large thirteen-star flags, for example, and American flags of different sizes (including both thirteen and fifty-star versions) were prominent. Many participants carried "Spirit of ' 76 " banners, or wore red, white and blue hats. One contingent, led by two people dressed as Revolutionary war drummers, appeared as the Founding Fathers - complete with colonial dress and giant papier-mâché heads. ${ }^{32}$ In her message of support to gay Angelinos, which was printed in the official programme, Massachusetts's openly gay state representative Elaine Noble argued,

We, as gays, must see that we are patriots, too, but of the age of the 1776 revolution. For we carry on the spirit of that revolution and of that age, and must continue that fight for personal freedoms and liberties that was started in this country so long ago.

Describing the Stonewall Riot as "our tea party," she urged a "renewed determination to see that spirit of ' 76 maintained, until freedom for all is truly

${ }^{28}$ GAA, “Repeal the New York Consensual Sodomy Statute!", in The Gay Rights Movement: Gay Activists Alliance; from the International Gay Information Center, New York Public Library, microfilm (New York: Research Publications International, 1998), Reel 17, Box 22, Folder 6, "Printed Ephemera, 1976-1977, 2, 3. See also http://paganpressbooks.com/jpl/ REPEAL.HTM and www.prideagenda.org/tabid/96/Default.aspx, accessed io Nov. 2010. For John Lauritsen see http://paganpressbooks.com/jpl/BIO.HTM, accessed I 2 Feb. 20 I 2."

${ }^{29}$ According to popular legend, Betsy Ross made the first American flag, and presented it to General George Washington.

30 "3 Cheers for red, white and gay," Chicago Tribune, 28 June 1976, Section 2, 5, in Craig Rodwell Papers, Box 4, folder "Christopher Street Liberation Day, 1976," New York Public Library (NYPL). See also "Gay Marches On," Villager, I July I 976, 2, in Craig Rodwell Papers, Box 4, folder "Christopher Street Liberation Day, 1976," NYPL.

${ }^{31}$ The Advocate, io March 1976, I I.

${ }^{32}$ Pat Rocco, dir., We Were There: A Celebration of Gay Pride in Our Bicentennial Year: San Francisco and Los Angeles Gay Pride Celebrations, 1976, NYPL. 
established in this country." ${ }_{33}$ Meanwhile Sharon Cornelsion, chair of Christopher Street West, argued that "Freedom and Justice for all ...' applies equally to both Gay people and straight people" and proclaimed her hope that the Bicentennial year would be "remembered as the year when Gay people all over the country could truly become GAY AND PROUD." 34

Leonard Matlovich also invoked patriotism in his attempt to overturn the US military's blanket ban on homosexuals. On 6 March I975, the thirty-oneyear-old technical sergeant in the US Air Force, who had served three tours of duty in Vietnam, winning the bronze star and purple heart, had delivered a letter to his supervising officer stating that he was a homosexual. He then engaged in a long legal battle to block the military's attempts to discharge him. Matlovich quickly became a high-profile figure, appearing on the front cover of Time in September 1975 (the first openly gay man to be afforded that honor), and speaking at gay pride rallies. For Matlovich, the fight for gay rights was a patriotic struggle. At a news conference held Friday i9 September 1975, shortly after an Air Force review board had recommended that he be given a general (i.e. less than honorable) discharge, a "smiling" Matlovich "held up a bicentennial half-dollar and said, "It says 200 years of freedom. Not yet ... but it will be some day." The following month at a fund-raising party held at Pier Nine, a gay disco in Washington, DC, Matlovich told a cheering crowd of supporters, "One day we, too, will be able to say, "My country, 'tis of thee, sweet land of liberty."' 35

Probably the most famous gay rights figure of the I970s was Harvey Milk, a charismatic neighbourhood activist who was elected to San Francisco's Board of Supervisors in 1977. Amid a growing backlash against gay rights - including the attempt by California State Senator John Briggs to exclude gay teachers from the public schools, and Anita Bryant's campaign to repeal a gay civil rights ordinance in Dade County, Florida - Milk attempted to harness the power of Americanism to the gay cause. Speaking before a massive crowd in San Francisco on 25 June 1978, Milk sought to "remind" his audience, and the

${ }^{33}$ July 4, '76. Christopher Street West Gay Pride Celebration, Bicentennial Issue, 5, NYPL.

${ }^{34}$ July 4, '76. Christopher Street West Gay Pride Celebration, Bicentennial Issue, 6, NYPL.

${ }^{35}$ Leslie Oelsner, "Homosexual Is Fighting Military Ouster," New York Times, 26 May 1 975, 33, 24; Jay Matthews and Donnel Nunes, "Homosexual GI Fights Release from Service," Washington Post, 28 May 1975, Aı, 6; Donald P. Baker, "Family Shifts," Washington Post, I7 Sept. 1975, A I, I2; "Air Force acts to oust homosexual sergeant," Chicago Tribune, 20 Sept. 1975, Wi ; Jeannette Smyth, "Matlovich: 'It's Not Me That's The Issue'," Washington Post, 25 Oct. 1975, Ai7; Martin Duberman, "Sex and the Military: The Matlovich Case (1976)," in Duberman, Left Out: The Politics of Exclusion/Essays/1964-2002 (Cambridge, MA: South End Press, 2002), 297-98, 3 I 3-1 4; "Armed Forces: Homosexual Sergeant," Time, 9 June 1975; "The Sexes: The Sergeant v. the Air Force," Time, 8 Sept. 1975; "Armed Forces: No to Matlovich," Time, 29 Sept. 1975; David Eisenbach, Gay Power: An American Revolution (New York: Da Capo Press, 2007), 262, 282. 
movement's enemies, "what America is." Milk brought together the Statue of Liberty's promise of a land where the poor and dispossessed might "breathe free," the Declaration of Independence's vision of a nation where "All men are created equal," and the national anthem's notion of the "land of the free," to encapsulate the nation's ideals. Then, turning directly to Briggs, Bryant and "all the bigots out there," Milk claimed,

That's what America is. No matter how hard you try, you cannot erase those words from the Declaration of Independence ... chip those words from off the base of the Statue of Liberty ... [or] sing the "Star Spangled Banner" without those words. That's what America is. Love it or leave it. ${ }^{36}$

In making the argument that opposing gay rights and seeking to roll back recent advances in the cause of gay equality ran counter to the nation's ideals, Milk was implying that Briggs, Bryant and their allies were un-American. But, perhaps reflecting a certain discomfort with a term that had been used so enthusiastically by politicians of the right during the McCarthy era, gay rights activists appear to have been reluctant to characterize their opponents explicitly as "un-American" during the i960s and I970s. In more recent decades, however, the language of un-Americanism has operated alongside that of Americanism to a far more noticeable degree.

\section{IV}

Over the last few years, much of the gay rights movement's energies have been focussed on the right to marry. Activists and organizations have mobilized at the state level to secure legal marriage, or to defend existing rights from conservative opponents. They have also launched attacks on the federal Defense of Marriage Act (1996), which defines marriage as between a man and a woman and permits individual states the right to not recognize same-sex relationships that are considered as marriage in another state. In these battles, LGBT activists and their allies have continued the tradition of invoking Americanism. Slogans on pro-gay marriage campaign placards, for instance, have included "We The People - that means all of us" and "Does it say: "All men are created equal - except for homos'?" 37 Marriage Equality USA was founded in 200I for the sole purpose of ending "discrimination in civil marriage so that non-heterosexual couples can enjoy the same legal and societal status as heterosexual couples." ${ }^{38}$ Its placard, which is a common sight at gay marriage demonstrations and rallies, illustrates the use of patriotic symbolism

\footnotetext{
${ }^{36}$ See Simon Hall, "The American Gay Rights Movement and Patriotic Protest," Journal of the History of Sexuality, 19, 3 (Sept. 2010), 559-560.

${ }^{37}$ See www.gaymarriagesigns.com, accessed I6 Feb. 20 I 2.

${ }^{38}$ See www.marriageequality.org/the-organization, accessed I 6 Feb. 20 I 2.
} 
nicely, with the slogan "Liberty, Justice \& Marriage Equality" and an image of the Statue of Liberty holding a wedding bouquet.

Activists have also used patriotic language in their public statements. Testifying before the Senate Judiciary Committee on 20 July 20 I I, during hearings to assess the impact of DOMA on American families, Jane A. Leyland outlined the importance of the right to marry. Despite having been in a committed and loving relationship with another woman, Terry, for more than twenty-seven years, the couple had been forced to wait until 2008 before their relationship was given legal recognition by the state of California. The "truly wonderful experience of being able to marry a person of one's choice," Leyland argued, was "a basic human right which all people should have and which is certainly on a par with the 'unalienable Rights ... [to] Life, Liberty, and the Pursuit of Happiness' as stated in the Declaration of Independence and for which governments are instituted to secure." 39 Other activists who testified shared similar sentiments. Jim Nimmo argued that "our system of American fair play needs to rescind DOMA," while Kathleen Cumiskey declared that "DOMA flies in the face of everything that we hold dear as Americans." 40

In California, the legal challenge to overturn Proposition 8 (a ballot measure, passed in November 2008, that restricted recognition of marriage to heterosexual couples) was led by the American Foundation for Equal Rights (AFER). Its guiding philosophy is that an "integral part of our nation's character and laws is the principle that all Americans are entitled to be treated equally by their government." 4 I AFER, which brought the Perry v. Schwarzenegger test case, appointed Ted Olson, solicitor general under George W. Bush and a "politically active, lifelong Republican" and David Boies (who had been Olsen's adversary in Bush v. Gore (2000)) as lead counsel..$^{22}$ Olsen himself supported gay marriage, believing it to be compatible with conservatives' traditional emphasis on stable family units, strong communities, and mutual obligations. Beyond this, though, he argued that the denial of gay marriage rights represented a violation of the nation's

39 "Statement of Jane A. Leyland before the Committee on the Judiciary, United States Senate," Submitted for the Record of a Hearing Entitled "S.598, The Respect for Marriage Act: Assessing the Impact of DOMA on American Families," 20 July 20 I I, I 95, 196, I 97, available at www.gpo.gov/fdsys/pkg/CHRG- I I 2shrg70639/pdf/CHRG- I I shrg70639.pdf, accessed 2 March 2012.

${ }^{40}$ Submissions for the Record of Don Chabot and Jill Nimmo, 75, and Kathleen Cumiskey and Robin Garber, 99, at www.gpo.gov/fdsys/pkg/CHRG-I I 2 shrg70639/pdf/CHRGI I 2shrg70639.pdf, accessed 2 March 20 I 2.

${ }^{41}$ See www.afer.org/our-work/our-arguments, accessed i 7 Feb. 20 I 2.

${ }^{42}$ See www.afer.org/about/legal-team, accessed I7 Feb. 2012; and Ted Olson, "The Conservative Case for Gay Marriage: Why Same-Sex Marriage Is an American Value," Newsweek Magazine, 8 Jan. 2010, available at www.thedailybeast.com/newsweek/2010/or/ 08/the-conservative-case-for-gay-marriage.html, accessed I 6 Feb. 20 I 2. 
founding promise of equality. According to Olsen, "Legalizing same-sex marriage would ... represent the culmination of our nation's commitment to equal rights." 43 On 7 February 2012, scores of gay rights activists marched to the James R. Browning courthouse in San Francisco, behind two giant flags (one rainbow flag, the other an American flag), ${ }^{44}$ to await the ruling of the ninth US circuit court of appeals. Shortly after the court ruled Proposition 8 unconstitutional, Olsen declared, "Today we are more American because of this decision." 45

Supporters of gay marriage have, though, also been prepared to deploy the ideas and rhetoric of un-Americanism and the un-American. On I 8 May 2005, Marvin Burrows, a seventy-five-year-old Air Force veteran, appeared before the California Assemblies Appropriations Committee in Sacramento. His powerful testimony has been used by the organization Marriage Equality USA as part of its Loving Quilt public outreach project. Burrows explained some of the consequences that flowed from the denial of the right to marry at state level, and the provisions of DOMA. He recalled that on the day that Bill Sweenor, his partner of fifty years, died,

I was told that even though I was his domestic partner, I did not have the right to make burial arrangements for him. I was denied access to Bill's retirement plan, social security benefits and my health benefits ended because of [DOMA] ... I was forced to move from the home we shared for over 30 years.

It was, declared Burrows, "unfair, and un-American that I should be left this way by my country." ${ }^{6}$ In his campaign for a gay marriage amendment to the US Constitution, activist Andrew Meyer has sought to convince members of both the House and Senate that the "numerous state bans and federal prohibitions that have been enacted in recent years are in flagrant violation of the founding principles of our Republic" and thus "intrinsically un-American." 47

${ }^{43}$ Olson.

${ }^{44}$ Bob Egelko, "U. S. Appeals Court Rules Prop.8 Unconstitutional," San Francisco Chronicle, 8 Feb. 2012, and video at www.sfgate.com/cgi-bin/article.cgi?f=/c/a/2012/02/08/ $\mathrm{MN}_{\text {I }} \mathrm{H}_{\mathrm{IN}} \mathrm{N}_{\mathrm{T}} \mathrm{H} . \mathrm{DTL}$, accessed 17 Feb. 20 I 2.

${ }^{45}$ Karen McVeigh, "Prop 8: California Gay Marriage Ban Struck down by Federal Appeals Court," The Guardian (London), 7 Feb. 2012, at www.guardian.co.uk/world/2012/feb/07/ prop-8-california-gay-marriage-ban-struck-down, accessed 7 Feb. 20 I 2.

${ }^{46}$ Burrows also submitted his testimony to the US Senate Judiciary Committee Hearings into DOMA. See "Statement of Marvin Burrows before the Committee on the Judiciary, United States Senate," Submitted for the Record of a Hearing Entitled "S.598, The Respect for Marriage Act: Assessing the Impact of DOMA on American Families," 20 July 20 I I, 65-69, available at www.gpo.gov/fdsys/pkg/CHRG- I I 2shrg70639/pdf/CHRG- I 2 shrg70639.pdf, accessed 2 March 20 I2; for the California testimony/Loving Quilt see www.marriageequality. org/Marvin-Bill, accessed 17 Feb. 20 I 2.

47 "About this Blog," at http://marriageequalityamendment.blogspot.com/2008/ I I/marriageequality-amendment.html, accessed I6 Feb. 2012; and "Letter to Congresswoman 
In November 2009, after Maine citizens voted narrowly to overturn the state's gay marriage law, Gay \& Lesbian Alliance against Defamation (GLAAD) president Jarrett Barrios commented, "It's wrong to take basic rights and protections away from neighbors, friends and co-workers who just want the same opportunity to care for their loved ones and families. It's wrong, unfair and, frankly, un-American" (in the November 2012 elections, Maine voters approved same-sex marriage by a margin of 53 to 47$) \cdot .^{48}$ Similarly, in March 20 I I, commenting on opinion polls that suggested that a majority of Americans supported gay marriage, AFER president Chad Griffin argued that it was "un-American to continue to deprive gay and lesbian couples of their fundamental constitutional right to marry." 49

Elected politicians and political activists have also used the combination of Americanism and un-Americanism to make the case for gay rights. In the spring of 2009 Meghan McCain, daughter of the Arizona Senator and 2008 Republican presidential nominee, wrote an open letter to New York Republicans urging their support for the state's proposed gay marriage bill. In strong language, McCain rooted her support for the measure in the principles of "equality under the law and personal freedoms" that "make America the greatest country in the world." Declaring that gay marriage would strengthen families and communities, as well as providing important legal protections to same-sex couples, she asserted that while "people may always have a difference of opinion ... championing a position that wants to treat people unequally isn't just un-Republican. At its fundamental core, it's un-American." so Speaking before reporters on 25 May $201 \mathrm{I}$, a few days after the Minnesota state legislature formally approved a proposed constitutional amendment that would ban same-sex marriage, Governor Mark Dayton (Dem) declared his opposition to the measure. Arguing that "all American citizens are entitled to equal protection under the law," Dayton appealed to voters to reject the amendment during the November 20 I 2 elections, claiming that "Minnesota is better than this, Minnesotans are better than this." Using uncompromising

Jane Harman," 20 Feb. 2009, at http://marriageequalityamendment.blogspot.com/2009/02/ california-xxxvii-congreswoman-jane.html, accessed i 6 Feb. 20 I 2.

48 "Statement by GLAAD president Jarrett Barrios on 2009 Election Results in Maine, Washington and Kalamazoo, Mich.," 4 Nov. 2009, at www.glaad.org/releases/statementglaad-president-jarrett-barrios-2009-election-results-maine-washington-and, accessed 23 Feb. 2012.

${ }^{49}$ See www.outtv.ca/blog/20 I I/03/23/third-national-poll-shows-a-majority-of-americanssupport-marriage-equality, accessed I6 Feb. 2012. See also www.afer.org, accessed I6 Feb. 20 I 2. For 2012 results see, for example, www.marriageequality.org/election-results, accessed 16 Nov. 2012.

${ }^{50}$ Meghan McCain, "Why the New York GOP Should Embrace Gay Marriage," New York Daily News, 22 May 2009, at http://articles.nydailynews.com/2009-05-22/news/ I7923273_I_marriage-bill-marriage-equality-log-cabin-republican, accessed I6 Feb. 20 I 2. 
language, the governor denounced the amendment as "mean-spirited, divisive, un-Minnesotan, and un-American" (the voters heeded Dayton's call, rejecting the amendment by 5 I percent to 48 percent). ${ }^{\text {s }} \mathrm{A}$ few months later, reflecting on the successful passage of a marriage-equality law in New York, Governor Andrew Cuomo described opponents of the measure as wanting to "discriminate against gay people." In a twist on the formulation used by the likes of McCain and Dayton, he claimed that this was "anti-New York. It's also anti-American." 52

Invocations of patriotism, and accusations of un-Americanism, also featured prominently in the effort by gay rights activists, and their political supporters, to repeal Don't Ask, Don't Tell. DADT, which was introduced by President Clinton in 1993 , prevented commanders from asking military personnel about their sexual orientation, but it barred openly lesbian, gay and bisexual Americans from serving in the armed forces. During the seventeen years that the policy operated, more than 13,000 servicemen and -women were discharged because of their sexual orientation. ${ }^{53}$ DADT had emerged as a compromise following Bill Clinton's efforts, during the first months of his presidency, to fulfil his election promise of ending the blanket ban on gays serving in the military. The ban itself had come under increasing attack from gay rights activists and their allies: in December 1989 , for example, in a nonbinding vote, the Faculty of the University of Wisconsin-Madison had called on the Regents to sever all contacts with the Reserve Officers Training Corps. As one leading figure in the campaign put it, "our main argument is that discrimination against any human being on grounds other than their personal qualifications is un-American, unfair and unjust." 54 The ban had also come under pressure from the courts and from federal officials, and from within the military.55 In 1993, during highly charged debates about repealing the ban, those on both sides of the issue had traded accusations of "un-Americanism."

${ }^{51}$ Mike Andrew, "Al Franken Speaks out for Marriage Equality in Minnesota," Seattle Gay News, 27 May 20 I I, at www.sgn.org/sgnnews39_2 I/page I 3.cfm, accessed i I Jan. 20 I 2. For November 20 I 2 results see www.marriageequality.org/election-results, accessed I 6 Nov. 20 I 2.

52 Julie Bolcer, "Gay Marriage Opponents Want Apology from Cuomo," The Advocate, 25 Oct. 20II, at www.advocate.com/News/Daily_News/20I I/I0/25/Gay_Marriage_ Opponents_Want_Apology_from_Cuomo, accessed i I Jan. 20 I 2.

53 “'Don't Ask, Don't Tell' Repeal Lets Gays, Lesbians Serve Openly," Los Angeles Times: Nation Now, 20 Sept. 20 I I, at http://atimesblogs.latimes.com/nationnow/20 I I/og/dontask-dont-tell-officially-repealed.html, accessed 23 Feb. 20 I 2.

54 "In Rare Vote, Faculty to Decide on ROTC," New York Times, 3 Dec. 1989, 67; "Ouster Voted for ROTC in Wisconsin," New York Times, 6 Dec. 1989, Bi 5; "Administrators Overrule Faculty and Back ROTC: Wisconsin," New York Times, 4 Feb. 1990, 44-45.

"5s For a brief summary see Chris Bull and John Gallagher, Perfect Enemies: The Religious Right, the Gay Movement, and the Politics of the Iggos (New York: Crown Publishers, Inc., 1996), I 25-29. 
Republican Senator and conservative icon Barry Goldwater called on Congress to summon the "courage to rally the troops in support of ending this unAmerican discrimination"; civil rights leader Coretta Scott King called the ban "un-American"; and gay rights activist Kevin M. Cathcart, executive director of the Lambda Defense and Education Fund, declared that "hatred in any form is un-American." ${ }^{6} 6$ Religious arguments and the invocation of traditional "family values" featured heavily in pro-ban rhetoric, but, in an echo of the McCarthy era, homosexuals were also presented as posing a serious, even an existential, threat to the nation. Some even claimed that repealing the ban would destroy the armed forces and, with it, the nation. In his 1993 diatribe Military Necessity and Homosexuality, for example, Ronald D. May claimed that gays posed an inherent security risk: "homosexuals, as a group or subculture, can and do turn against their country simply on account of the nature of homosexuality and its hostile attitude toward the existing moral order." He also characterized the gay rights movement as a "domestic enemy" that threatened to "kill America's soul and destroy the legacy of our founders." In this formulation, then, the gay rights movement constituted the very epitome of the un-American. ${ }^{57}$

As the 2008 presidential campaign approached, the Human Rights Campaign (which was founded in 1980 to work for LGBT equality) worked hard to make DADT an election issue. For three days, beginning on 30 November 2007, the organization helped to host "I 2,000 Flags for I 2,000 Patriots," a tribute on the National Mall to the thousands of men and women who had been thrown out of the military since the enactment of DADT. Each of the American flags placed on the Mall would, stated HRC, "stand as a testament to the waste to our military, our security, and our country caused by this discriminatory law." 8 Gay and lesbian soldiers who had been expelled from the military, as well as those still serving, played an important role in the campaign against DADT.59 For example, on 20 April 20 10, Mara Boyd, an Air Force cadet who had been discharged after coming out to her commanding officer, joined five other veterans who handcuffed themselves to the fence

56 "Bigotry Is What's Incompatible," New York Times, 6 July 1993, Aı6; Kevin M. Cathcart,

"Gay Cause Is the Same as Black Cause," New York Times, io July I 993 , I 8.

${ }^{57}$ Bull and Gallagher, $133-34$, I 37-38, I 5 I.

58 "The HRC Story: About Us," at www.hrc.org/the-hrc-story/about-us; and "' 2,000 Flags for I 2,000 Patriots' Tribute Will Honor American Soldiers Discharged under DADT," at www.hrc.org/blog/entry/ I 2000-flags-for- I 2000-patriots-tribute-will-honor-american-soldiersdischar, both accessed 23 Feb. 20 I 2.

59 Josh Seefried ("JD Smith"), a first lieutenant in the US Air Force, organized OutServe, an organization of LGBT troops, that campaigned for the repeal of DADT. See www. thedailybeast.com/articles/20 I I/09/ I 9/don-t-ask-don-t-tell-ends-a-gay-soldier-comes-out. html, accessed 23 Feb. 2012. 
outside the White House to protest DADT. For Boyd, this act of civil disobedience provided an opportunity to "continue to serve my country" by opposing "a policy that is wrong and, frankly, un-American."60

Following Barack Obama's campaign promise to repeal DADT, a concerted effort was made to change the policy during 2010 . Speaking in favour of repeal on the floor of the House on 27 May 20 Io, speaker Nancy Pelosi urged her colleagues to "make America more American." Wisconsin's openly gay representative Tammy Baldwin (who was elected to the Senate in November 20 I2) declared, "In the land of the free and the home of the brave, it is long past time for Congress to end this un-American policy." Joseph Lieberman, a leading opponent of DADT in the Senate, claimed that the policy "doesn't serve the best interests of our military and doesn't reflect the best values of our country." The discharge of thousands of soldiers, sailors, marines and airmen "not because they were inadequate ... but because of their sexual orientation" was, argued Lieberman, "not what America is all about." ${ }^{1}$ Following Congressional approval on i 8 December 2010, President Obama signed the repeal into law four days later. ${ }^{62}$ Speaking at the signing ceremony, the President declared,

we are not a nation that says, "don't ask, don't tell." We are a nation that says, "Out of many, we are one." We are a nation that welcomes the service of every patriot. We are a nation that believes that all men and women are created equal. Those are the ideals that generations have fought for. Those are the ideals that we uphold today. And now, it is my honor to sign this bill into law. ${ }^{63}$

To allow for training and preparation, implementation of the repeal was delayed; it eventually came into effect on 20 September 20II. As they celebrated their victory, both gay rights campaigners and their prominent political supporters fused together Americanism and the un-American. Senator Patrick Leahy (Dem - VT), for example, issued a statement in which he said,

Last week, we celebrated the 224th anniversary of the United States Constitution, the document that enshrines the ideals we cherish in this country. These are the ideals that the men and women who wear the uniform fight to protect. Yet for the past I 8 years,

${ }^{60}$ Robin Petré, "Fighting an "un-American" Policy," In These Times, 9 Aug. 2010, at www. inthesetimes.com/article/6203/fighting_an_un-american_policy, accessed 23 Feb. 2012.

${ }^{6 r}$ David M. Herzenhorn and Carl Hulse, "House Votes to Allow 'Don't Ask, Don't Tell' Repeal," New York Times, 27 May 2010 , at www.nytimes.com/2010/05/28/us/politics/28tell. html, accessed 23 Feb. 20 I 2.

${ }^{62}$ A history of "Don't Ask, Don't Tell," at www.washingtonpost.com/wp-srv/special/politics/ dont-ask-dont-tell-timeline, accessed 23 Feb. 2012.

${ }^{63}$ Gautam Raghavan, “Don't Ask, Don't Tell Repeal One Year Later: 'Out of Many, We Are One'”, at www.whitehouse.gov/blog/201 I/1 2/22/dont-ask-dont-tell-repeal-one-year-laterout-many-we-are-one, accessed 23 Feb. 2012. 
gays and lesbians serving in the military have not been free to be honest about who they are. For nearly two decades, we have demanded that they hide a part of their identity if they wish to wear the uniform and fight for our ideals. The now-ended policy of "Don't Ask, Don't Tell" is fundamentally un-American. It is wrong. And I am proud to say that today, it is fully and finally repealed. ${ }^{64}$

In Portland, Oregon the local HRC steering committee joined with other community groups and activists to celebrate. The proceedings began with a "powerful rendition of the National Anthem on trumpet" by the HRC's John Kim, followed by speeches by the mayor and lesbian veterans who had been discharged under DADT. That evening, more than a hundred people gathered at the local LGBT resource centre for a party. The day's programme had been organized under the patriotic slogan "As American as Apple Pie: A Day of Celebration and Remembrance!"6s

\section{V}

Invoking Americanism is in many ways an attractive strategy. It enables activists to deploy language and symbols that resonate powerfully, and to tap into a deep-rooted protest tradition that has proven successful in the past. It is, perhaps, especially appealing to minority groups since it offers an opportunity to reach out and build support on the basis of shared values and ideals. As Ted Olsen put it,

Americans who believe in the words of the Declaration of Independence, in Lincoln's Gettysburg Address, in the 14th Amendment, and in the Constitution's guarantees of equal protection and equal dignity before the law cannot sit by while this wrong [the denial of marriage rights] continues. This is not a conservative or liberal issue

- or, he might have added, simply a "gay" issue - "it is an American one, and it is time that we, as Americans, embraced it." 66

The increasing willingness of activists and their supporters to argue that those who seek to deny lesbian, gay, bisexual and transgender Americans their rights are un-American, or taking an un-American position, is, however, striking. This development might be a conscious riposte to the political right's use of un-Americanism, or a legacy of the culture wars and their rhetorical excess. It certainly seems in keeping with the tone of contemporary political culture. The 2012 presidential campaign saw Republican hopeful Herman Cain denounce Occupy Wall Street as "un-American," and House Majority

\footnotetext{
${ }^{64}$ Bridgette P. LaVictoire, "Reactions Abound on Repeal of DADT," 2 I Sept. 201 I, at http://lezgetreal.com/20 I I/o9/reactions-abound-on-repeal-of-dadt, accessed 23 Feb. 2012.

65 "DADT Repeal and Apple Pie for America," at www.hrc.org/blog/entry/dadt-repealand-apple-pie-for-america, accessed 23 Feb. 2012.

${ }^{66}$ Olson, "The Conservative Case for Gay Marriage."
} 
Leader Eric Cantor describe the protesters as "mobs" that were engaged in "assaults on many of our nation's bedrock principles." 67 Meanwhile, former House speaker Newt Gingrich charged that President Obama's talk of the 99 percent and the I percent was un-American, while voicing his own frustration with "elitist judges" seeking to impose their "radically un-American views." ${ }^{68}$ Sarah Palin described Barack Obama's insistence that health insurance plans cover contraception as "an un-American act" and "a violation of those things that our Founders fought and died for." ${ }^{6}$ Democrats, meanwhile, have charged their opponents with taking an un-American stance or engaging in un-American behaviour in the heated debates over health care reform and immigration policy, as well as gay rights. ${ }^{\circ}$

By deploying the language of Americanism and un-Americanism, activists, commentators and politicians turn controversial questions about which citizens sometimes disagree in good faith, and elevate them into fundamental questions about the nature, character and meaning of the republic itself. Raising the political and rhetorical stakes in this way makes compromise and pragmatism more difficult, and perhaps encourages a more divisive (and at times bad-tempered) political culture. It leads, as historian Daniel Matlin has pointed out, to political opponents being "branded not simply as erroneous or misguided, but as alien, illegitimate, and deserving of exclusion." ${ }^{71}$ It is hardly surprising, then, that those accused of being un-American often react badly. Many religious conservatives believe that homosexuality is a sin; that gay marriage threatens the stability of the family and, with it, society at large; and that in opposing gay marriage they are defending the traditional moral values

${ }^{67}$ John Nichols, "Hypocrisy Share Values Soar as Tea Party Republicans Accuse Occupy Wall Street of 'Dividing Americans'," The Nation, 7 Oct. ber 201 I, at www.thenation. $\mathrm{com} / \mathrm{blog} / \mathrm{I} 63867 /$ hypocrisy-share-values-soar-tea-party-republicans-accuse-occupy-wall-streetdividing-ame, accessed i 7 Feb. 2012.

${ }^{68}$ Steve Benen, "What Gingrich Doesn't Want to Talk about," Washington Monthly, Political Animal Blog, 29 Nov. 20II, at www.washingtonmonthly.com/political-animal/20II_I I/ what_gingrich_doesnt_want_us_t033780.php, accessed I7 Feb. 2012; David G. Savage, "Newt Gingrich Says He'd Defy Supreme Court Rulings He Opposed," Los Angeles Times, I 7 Dec. 20 I I, at http://articles.latimes.com/20 I I/dec/1 $7 /$ news/la-pn-gingrich-judges-20 I I 2 I 7 , accessed 17 Feb. 20 I 2.

69 "Palin: Obama Actions 'Un-American.' We're Rising Up," at http://nation.foxnews.com/ sarah-palin/2012/02/1 5/palin-contraception-rule-unconstitional-act-obama-and-were-rising, accessed 17 Feb. 20 I 2.

${ }^{70}$ William Lajeunesse, "Pelosi Tells Illegal Immigrants That Work Site Raids are UnAmerican," Fox News, I 8 March 2009, at www.foxnews.com/politics/2009/03/18/pelositells-illegal-immigrants-work-site-raids-american, accessed 24 Feb. 20I2; and Erica Werner, "Pelosi, Hoyer: Disrupting Town Halls 'Un-American'," Huffington Post, io Aug. 2009, at www.huffingtonpost.com/2009/08/10/pelosi-hoyer-town-hall-pr_n_255359.html, accessed 24 Feb. 2012.

${ }^{71}$ Daniel Matlin, "Social Movements and Radicalism in Post-War American History," Historical Journal, 55, I (March 2012), 263-75, 269. 
on which the United States was founded. ${ }^{72}$ Following Andrew Cuomo's remarks in October 20II, Rev. Jason McGuire, executive director of New Yorkers for Constitutional Freedoms-a group of evangelical Protestants opposed to gay marriage - wrote an open letter to the governor, urging him, "Retract your comments and apologize to millions of New Yorkers and other proud Americans you have offended." 73

Finally, gay rights activists' consistent and prominent appeals to Americanism, and their increasing willingness to deploy the term "un-American," raise intriguing and at times troubling questions about both the politics of the gay rights movement and its relationship with American nationalism. In her 2003 book The Twilight of Equality, Lisa Duggan attacked the rise of a "neoliberal 'equality' politics" that has moved the focus of the gay rights movement away from "constituency mobilization and community-based consultation" in favour of lobbying, litigation, and public relations. ${ }^{74}$ Led by prominent writers such as Andrew Sullivan and Bruce Bawyer, and organizations including the Human Rights Campaign and the Independent Gay Forum, this "neoliberal gang" has championed a politics that, rather than contesting "dominant heteronormative assumptions and institutions" instead "upholds and sustains them, while promising the possibility of a demobilized gay constituency and a privatized, depoliticized gay culture anchored in domesticity and consumption." 75 Duggan has pointed out that in embracing the American Dream and emphasizing conservative family values (such as monogamy, commitment, stability and responsibility) in making the case for gay marriage, some activists and organizations have produced "rhetoric that insults and marginalizes unmarried people" and used "much the same terms as the welfare reformers use to stigmatize single-parent households, divorce, and 'out of wedlock' births." "If pursued in this way," Duggan explains, "the drive for gay-marriage equality can undermine rather than support the broader movement for social justice and democratic diversity." ${ }^{6}$ Of course, the neoliberal approach to gay rights - with its heavy focus on marriage rights and

${ }^{72}$ See, for example, Mike Stout, letter to the editor, "Same-Sex Marriage Foes Are Not Being Un-American," 27 Oct. 2011, at http://blog.syracuse.com/opinion/201 I/ro/same-sex_ marriage_foes_are_not.html, accessed 24 Feb. 2012.

${ }^{73}$ Julie Bolcer, "Gay Marriage Opponents Want Apology from Cuomo," The Advocate, 25 Oct. 2011, at www.advocate.com/News/Daily_News/201 I/I0/25/Gay_Marriage_ Opponents_Want_Apology_from_Cuomo, accessed i I Jan. 20 I 2.

${ }^{74}$ Lisa Duggan, The Twilight of Equality? Neoliberalism, Cultural Politics, and the Attack on Democracy (Boston: Beacon Press, 2003), 45.

${ }^{75}$ Ibid., 50.

${ }^{76}$ Lisa Duggan, "Holy Matrimony!" (2004), in Lisa Duggan and Nan D. Hunter, Sex Wars: Sexual Dissent and Political Culture, ioth anniversary edn (New York: Routledge, 2006), 227-28. For perhaps the most famous and influential "conservative" case for gay marriage see Andrew Sullivan, "Here Comes the Groom: A (Conservative) Case for Gay Marriage," New Republic (1989), reprinted at www.slate.com, 9 Nov. 2012, available at www.slate.com/ 
military service - has not gone unchallenged. Interviewed in June 2000, Martin Duberman - the prominent historian, playwright and gay rights activist - doubtless spoke for many when he explained,

my issues are not whether we should be allowed to join the killing machine, and whether or not we should beg the state to legalize our unions. I'm much more interested in how we can dismantle the killing machine and how we can challenge the orthodoxies relating to marriage. ${ }^{77}$

Nevertheless, Duggan is correct to warn that the "homonormative" approach risks squeezing out progressive visions of a more radical gay rights movement, working in concert with workers, minorities, and other oppressed or marginalized people to challenge the capitalist system. ${ }^{78}$

The neoliberal approach has also led some gay rights organizations and activists to support, or appear to support, US "imperialism" (or at least overseas military interventions) during the so-called War on Terror. Duggan argued that the post-9/ I I climate gave particular encouragement to activists to emphasize the "Americanism" of "model gay 'heroes' and 'victims" in order to provide a "rhetorical boost" to demands for gay marriage and the right to serve openly in the military.79 Andrew Sullivan was one of many who highlighted the fact that Mark Bingham, a rugby-playing jock who helped storm the cockpit of United Airlines Flight 93 in the skies above Pennsylvania, was gay. Sullivan sought to use this "national hero" to urge those who had caused "pain and heartache and cruelty" to gay men and women to rethink their attitudes. ${ }^{8 \circ}$ Duggan also cited the National Coalition of Anti-Violence Programs (NCAVP) - a gay rights coalition that advocates for "victims of anti-LGBT and anti-HIV/AIDS violence/harassment, domestic violence, sexual assault, police misconduct and other forms of victimization." ${ }^{8}$ Shortly after the war against Afghanistan began in the autumn of 2001, the NCAVP criticized a photograph of a US missile daubed with the slogan "Hijack this fags" as a "serious instance of gay-bashing," and praised the service of "honorable" "gay, lesbian and bisexual" military personnel. When it came to the morality of the conflict itself, NCAVP remained silent..$^{82}$

Building on Duggan's work, Jasbir K. Puar has developed the concept of "homonationalism" to highlight how, in the aftermath of 9/I I, a sense of nationalism infused the gay rights movement. She has also explored the ways

articles/news_and_politics/politics/2012/I I/gay_marriage_votes_and_andrew_sullivan_his_ landmark_1989_essay_making_a.html, accessed I 6 Nov. 20 I 2.

${ }_{77}$ Adam Nagourney, "For Gays, a Party In Search of a Purpose," New York Times, 25 June $2000,30$.

${ }^{80}$ Ibid., 63.

81 "About NCAVP: Our Mission," at http://ncavp.org/about/default.aspx, accessed I 6 Nov. 2012.

${ }^{82}$ Duggan, The Twilight of Equality?, 46-47. 
in which claims to "progressive sexuality" have been used by the American state to champion its "modernity" and to justify its overseas military interventions (by, for example, stressing the "liberation" of Afghan women, or presenting the United States as a "safer" space for homosexuals than the Middle East). ${ }^{8} 3 \mathrm{Her}$ 2007 book, Terrorist Assemblages, a landmark work in queer studies, discussed the "collusion between homosexuality and American nationalism that is generated both by national rhetorics of patriotic inclusion and by gay and queer subjects themselves." ${ }^{4}$ She was especially keen to map the "intersections, confluences, and divergences between homosexuality and the nation, national identity, and nationalism - the convivial, rather than antagonistic, relations between presumably nonnormative sexualities and the nation." ${ }_{5}$ Arguing that sexuality has had a "crucial presence in American patriotism, warmongering, and empire building," ${ }^{6}$ Puar explored the "pernicious inhabitation of homosexual exceptionalism" that occurred "through stagings of U.S. nationalism via a praxis of sexual othering" that "exceptionalizes the identities of U.S. homosexualities vis-à-vis Orientalist constructions of "Muslim sexuality." 87 Homonationalism, then, replicates the normative (and narrow) class, racial, religious and gender ideals that characterize (and divide) the nation. ${ }^{88}$ Writing in Social \& Cultural Geography, Deborah Cowen declared that Puar had demonstrated that "contemporary imperialism's moral claims to freedom and enlightenment require the rainbow flag," and showed how the "rejuvenation of nationalism through the incorporation of progressive sexuality, and the transformation of LGBTQ politics through growing entanglement in nationalism and militarism, are organized through racism." ${ }_{9} 9$

In response to the terrorist attacks on New York and Washington, gay activists and organizations, said Puar, "took up the patriotic call":

The American flag appeared everywhere in gay spaces, in gay bars and gay gyms, and gay pride parades became loaded with national performatives and symbolism: the pledge of allegiance, the singing of the national anthem, and floats dedicated to national unity. ${ }^{\circ}$

But this should come as no surprise: for half a century gay rights activists have invoked the language of Americanism and appealed to national ideals in their struggle for equal rights. What Puar labels "homonationalism" is part of a long and deep-rooted protest culture that, at times, has led gay rights activists to support, or to appear to support, American foreign policy and overseas entanglements. When homophile groups argued that the Cold War-era policy

\footnotetext{
${ }^{83}$ Jasbir K. Puar, Terrorist Assemblages: Homonationalism in Queer Times (Durham: Duke University Press, 2007), 380-39, 41, 43.

${ }^{85}$ Ibid., $49 . \quad{ }^{86}$ Ibid., 37. ${ }^{87}$ Ibid., $4 . \quad{ }^{88}$ Ibid., xxiv-xv.

${ }^{89}$ See Deborah Cowen's review of Terrorist Assemblages in Social \& Cultural Geography, I I, 4 (June 2010), 399-401, 400 .

${ }^{\circ}$ Puar, 43.
} 
of automatically excluding gay people from government employment was "not consistent with the national welfare" and worked "against the best interests of the country," for example, they re-enforced rather than challenged America's claims to democratic leadership against a worldwide communist enemy. During the mid-1970s, Leonard Matlovich's bid to remain in the US Air Force was embraced as a cause célébre, despite the fact that he had fought, and killed, for his country, in what many viewed as an immoral, unjust and racist war in Vietnam. And while the National Gay and Lesbian Task Force and the Human Rights Campaign may have demonstrated "little political reaction to the invasion of Afghanistan (and subsequently have been more preoccupied with gay marriage campaigns and gays in the military than the occupation of Iraq)," it is worth recalling that the GAA, one of the most important gay rights organizations to emerge in the post-Stonewall era, maintained a resolutely single-issue focus (it was "completely and solely dedicated" to achieving gay rights), even as debates over the war in Vietnam swirled around it.9 ${ }^{1}$

The use of Americanism (and, indeed, un-Americanism) as a protest strategy need not preclude radical challenges to US foreign policy, imperialism, militarism or capitalism. After all, Martin Luther King Jr. regularly invoked the Declaration of Independence and the American Dream precisely in order to denounce US military interventions abroad and entrenched economic inequality at home. ${ }^{22}$ In laying claim to Americanism, and by turning the charge of "un-Americanism" against their opponents, gay rights activists have championed a more inclusive, democratic and radical interpretation of the nation's founding promise, and present-day meaning. Nevertheless, that legal advances for gay Americans have been used to frame the United States as "modern" and "progressive" while justifying military interventions overseas is certainly troubling. Meanwhile the recent silence of some prominent gay rights activists and organizations on important questions of war and peace, and their sometimes uncritical use of Americanism and un-Americanism regardless of its potential costs, not least in re-enforcing existing divisions over class, gender, and race, will be profoundly unsettling to those who hold fast to transgressive, progressive or radical visions of gay liberation.

${ }^{91}$ Ibid., 43; Simon Hall, American Patriotism, American Protest, 40.

${ }^{92}$ See Hall, American Patriotism, American Protest, I 3; and Michael Eric Dyson, I May Not Get There with You: The True Martin Luther King, Jr. (New York: Free Press, 2001), chapter 4. 